\title{
Fas promoter -670 polymorphism and the risk of cervical cancer: A case-control study in multi-ethnic Malaysia
}

\author{
Yee Hock Tan ${ }^{* 1,5}$, Sharifah Noor Akmal Syed Husain ${ }^{2}$, Shiran Mohd Sidik ${ }^{3}$, Rozita Rosli ${ }^{1}$, Pei Pei Chong ${ }^{4}$ \\ ${ }^{1}$ Department of Biomedical Science, Faculty of Medicine and Health Sciences, Universiti Putra Malaysia, Selangor, Malaysia \\ ${ }^{2}$ Department of Pathology, Faculty of Medicine, Universiti Kebangsaan Malaysia, Kuala Lumpur, Malaysia \\ ${ }^{3}$ Faculty of Medicine and Defence Health, National Defence University of Malaysia, Kuala Lumpur, Malaysia \\ ${ }^{4}$ School of Bioscience, Faculty of Health and Medical Sciences, Taylor's University, Selangor, Malaysia \\ ${ }^{5}$ Department of General Studies, Faculty of Social Sciences and Liberal Arts, UCSI University, Kuala Lumpur, Malaysia
}

Received: December 15, 2017

Accepted: March 15, 2018

Online Published: April 17, 2018

DOI: $10.5430 /$ jer.v4n2p1

URL: https://doi.org/10.5430/jer.v4n2p1

\begin{abstract}
Background/Objective: Single nucleotide polymorphism (SNP) is a commonly occurring DNA sequence variation within the human population. The prevalence of these sequence variations differs in various populations and may lead to the suboptimal regulation of genes, including those of the apoptosis pathway. The regulation of cellular death is partially controlled by the interaction between tumor necrosis factor receptor family gene, Fas and its ligand, FasL. A base substitution in Fas -670 A $>$ G (rs1800682) has been found to alter the binding affinity of the Fas protein to its activators, potentially altering its apoptotic potential. The lack of proper apoptosis regulation can lead to a wide plethora of human conditions involving uncontrolled cellular growth such as cancer. The purpose of the study was to investigate whether there was any association between the Fas -670 polymorphism and risk of cervical cancer in multi-ethnic Malaysian women.

Methods: Using restriction fragment length polymorphism (RFLP-PCR), Chi-square and logistic regression analysis, this study investigated the Fas -670 SNP and its associations with cervical cancer in the multi-ethnic population of Malaysia.

Results: No significant associations were found between Fas -670 A>G SNP and risk of cervical cancer using the genotype model, dominant model and allele frequency model analysis, even after stratification into the Malay, Chinese and Indian ethnic subgroups; and cancer types.

Conclusion: Our results showed that the A $>$ G SNP of Fas -670 does not affect the risk of cervical carcinogenesis in Malaysian females.
\end{abstract}

Key Words: Fas, SNP, rs1800682, Cervical cancer, Malaysia

\section{INTRODUCTION}

Apoptosis, the process of programmed cell death, is critical in a multitude of developmental processes, which includes the regulation of damaged cells and the maintenance of tis- sue homeostasis. ${ }^{[1]}$ The regulation of apoptosis in the human body is triggered by two main apoptotic mechanisms; the extrinsic receptor mediated pathway and the intrinsic mitochondrial pathway. ${ }^{[2]}$ The proper function of components in

\footnotetext{
* Correspondence: Yee Hock Tan; Email: alantyh87@gmail.com; Address: Department of Biomedical Science, Faculty of Medicine and Health Sciences, Universiti Putra Malaysia, UPM Serdang, 43400, Selangor, Malaysia.
} 
both pathways ensures that compromised cells are dealt with swiftly and effectively via a series of mechanisms resulting in the dysfunction of the membrane, shrinkage of the cells, condensation of the chromatin and the DNA degradation of abnormal cells. ${ }^{[3]}$ The death of these cells is often necessary for preventing the onset of malignancy in the body. However, genetic variability in the genes associated with the mechanism of apoptosis can potentially compromise regulatory function resulting in abnormal growth and cancer. ${ }^{[4]}$

Cervical cancer is one of the most common cancers found in females worldwide. Approximately 527,600 new cases were reported and 265,700 deaths were attributed to cervical cancer cases worldwide in 2012 alone. ${ }^{[5]}$ In the multi-ethnic population of Malaysia, cervical cancer is the $3^{\text {rd }}$ most common female cancer attributing towards $7.7 \%$ of all cancer cases in females throughout 2007 to 2011. Cervical cancer was found to be most prevalent in Chinese females, followed by Indian and Malay females with an age standardized rate (ASR) of 9.8, 7.6 and 5.1 respectively. ${ }^{[6]}$ The main culprit in cervical carcinogenesis is the human papillomavirus (HPV). ${ }^{[7]}$ The high risk oncogenic types of this sexually transmitted virus are found in almost every cervical carcinoma case and are considered to be an essential factor in cervical transformation. ${ }^{[8]}$ Even so, infection with HPV in the cervical cells rarely progresses with cervical malignancy, ${ }^{[9]}$ as infected cells could be subjected to cellular death via apoptosis by the human immune system. Up to $99.7 \%$ of cervical carcinoma cases worldwide can be found with traces of HPV, ${ }^{[8]}$ but less than $1 \%$ of HPV infected conditions actually proceeds into malignancy. ${ }^{[9]}$

One of the most important triggers of apoptosis in the receptor mediated pathway is the interaction between the Fas (TNFSF6, CD95/APO-1) [GenBank: 31968] protein and its ligand, FasL. ${ }^{[10-12]}$ The Fas gene is a member of the tumor necrosis factor receptor family, capable of triggering a death signal cascade which leads to cellular apoptosis via cytotoxic T-lymphocytes and NK cells. ${ }^{[12-14]}$ The expression of Fas has been found highly regulated in a multitude of cells, including the basal squamous cells of the cervix. ${ }^{[15]}$ Hence, variations in the expression of the Fas genes within these cells could directly affect apoptosis. In addition to that, Fas expression is detectable alongside the presence of high risk HPV-16 and HPV-18, ${ }^{[16]}$ suggesting that the regression of HPV infection in cervical cells can potentially be affected by Fas -induced cellular apoptosis targeting HPV infected cells, eliminating them before the viral copy reaches critical mass and triggers neoplasia.

One of the many conditions which may alter Fas expression in the cervix is the occurrence of a single nucleotide poly- morphisms (SNPs) within the promoter region of the Fas gene. ${ }^{[17]}$ Of particular interest is Fas $-670 \mathrm{~A}>\mathrm{G}$ (rs1800682) found at the STAT1 transcription factors binding site. ${ }^{[18]}$ The STAT1 proteins function as signal transducers and transcription activators for the Fas gene. ${ }^{[19]}$ The substitution from A to $\mathrm{G}$ at this SNP has been found to produce a Fas protein with differing binding affinity to STAT $1^{[20]}$ altering the promoter activity of Fas and causing a change in the apoptotic potential. Moreover, since the prevalence of SNP varies from one population to the next, certain populations may inherently have a lower apoptosis potential and subsequently be more susceptible towards harbouring HPV infected cells, predisposing them to cervical carcinoma.

In this case-control study, the prevalence of Fas -670 SNP in females of various ethnic groups residing in Malaysia was investigated in order to identify associations with cervical cancer.

\section{METHODS}

\subsection{Study subjects}

A total of 313 cervical samples from females from the three main ethnic groups (Malay, Chinese and Indian) in Malaysia were included for this study. From these, 204 Thin Prep samples processed at National University of Malaya Hospital (HUKM) from 2008 to 2011 for Papanicolaou (PAP) smear screening were randomly selected and designated as the control group. These control samples were previously tested negative for HPV and negative for intraepithelial lesions and malignancy (NILM). Subsequently, 109 archival formalin fixed paraffin embedded (FFPE) tissue samples, were also randomly selected from the same hospital and designated as the case group. These tissue samples were also collected from 2008 to 2011, have been previously diagnosed with either squamous-cell carcinoma (SCC) of the cervix, cervical adenocarcinoma (ADC) or cervical adenosquamous carcinoma (ADSC). Table 1 shows the distribution of controls and cases across the three ethnics of Malaysia and the distribution of cases according to carcinoma type.

Table 1. Study population characteristics

\begin{tabular}{llll}
\hline Character & Control & Cases & Total \\
\hline $\begin{array}{l}\text { Mean age } \\
\text { (Range) }\end{array}$ & 40.89 & 52.72 & 45.01 \\
Ethnicity & $(21-73)$ & $(24-84)$ & $(21-84)$ \\
Malay & & & \\
Chinese & 66 & 56 & 122 \\
Indian & 97 & 35 & 132 \\
Carcinoma type & 41 & 18 & 59 \\
NILM & & & \\
Squamous cell carcinoma (SCC) & 204 & & \\
Adenocarcinoma (ADC) & & 36 & \\
Adenosquamous carcinoma (ADSC) & & 70 & \\
\hline
\end{tabular}


Institutional ethics approval for carrying out the study was obtained from the Medical Research and Ethics Committee of National University of Malaysia (Universiti Kebangsaan Malaysia), prior to commencing the experiments. Informed consent was also obtained from the study participants. DNA extraction was done using QIAAMP DNA Mini Kit (Qiagen $\mathrm{GmbH}$, Germany).

\subsection{Identification of Fas -670 single nucleotide polymor- phism}

Restriction fragment length polymorphism (RFLP) was used to identify the single nucleotide polymorphism for both case and control samples. After DNA extraction, PCR amplification was carried out using the following primers: - Fas -F: 5'-GGC GCA ACA TCT GTA CTT T-3' (forward) and Fas -R: 5'-CAG GAG CCT TGG CTA ATT-3'-3' (reverse).

The primers were modified from those described in a previous study, ${ }^{[17]}$ producing shorter amplicons which improves the amplification process for genomic DNA derived from archival FFPE tissue samples.

\subsection{Polymerase chain reaction}

The polymerase chain reaction (PCR) was carried out in duplicates for each sample. Each $50 \mu \mathrm{l}$ reaction contains 0.2 to $0.5 \mu \mathrm{g}$ of genomic DNA, $0.2 \mu \mathrm{M}$ each of both forward and reverse primers, $0.2 \mathrm{mM}$ of each of the four deoxynucleotide phosphates, $1 \times$ PCR buffer and $1.25 \mathrm{U}$ of EURx Taq polymerase (Roboklon GmbH, Germany). PCR amplification was carried out using BIORAD C1000 Thermal Cycler (BioRad Laboratories, USA) using the following protocol: Initial denaturation temperature of $94^{\circ} \mathrm{C}$ for 5 minutes; 35 cycles of $94^{\circ} \mathrm{C}$ for 30 seconds, $55^{\circ} \mathrm{C}$ for 30 seconds and $72^{\circ} \mathrm{C}$ for 45 seconds; and a final extension step at $72^{\circ} \mathrm{C}$ for 5 minutes. Gel electrophoresis was carried out using a 1.5\% agarose gel (Sigma-Aldrich, USA) with ethidium bromide staining. The PCR fragments were visualized using a UV transilluminator. The primers amplify a $149 \mathrm{bp}$ segment of the Fas promoter region carrying the $-670 \mathrm{~A}>\mathrm{G}$ single nucleotide polymorphism site.

\subsection{Fas PCR purification and RFLP}

After confirmation of amplification, the sample amplicons were purified using GeneJET PCR purification kit (Thermo Fisher Scientific, USA). An aliquot (50 ng) of the purified products was treated with the FastDigest restriction enzyme MvaI (Thermo Fisher Scientific, USA). Gel electrophoresis was carried out for the resulting amplicons using a 3\% agarose gel, pre-stained with ethidium bromide. The gel was then viewed under a UV trans-illuminator. The MvaI enzyme digests the $149 \mathrm{bp}$ amplicons if the SNP substitution $A>G$

Published by Sciedu Press was present producing two bands of $105 \mathrm{bp}$ and $44 \mathrm{bp}$ respectively. The AA genotype remains undigested by the MvaI restriction enzyme, maintaining the 149 bp band, whereas the GG genotype is fully digested showing the $105 \mathrm{bp}$ and $44 \mathrm{bp}$ bands. The heterozygous AG genotype is partially digested and will show the $149 \mathrm{bp}, 105 \mathrm{bp}$ and $44 \mathrm{bp}$ bands simultaneously. Verification of the RFLP results was done by sequencing the PCR products for $10 \%$ of the samples (1st

Base Laboratories, Malaysia).

\subsection{Data analysis}

Data was analyzed using Statistical Package for Social Sciences (SPSS). MvaI allele frequencies association with cervical cancer risk was determined using crude odds ratio (OR) and $95 \%$ confidence intervals $(95 \% \mathrm{CI})$ acquired from $\chi^{2}$ statistical test. Unconditional logistic regression analysis was carried out to acquire the adjusted odds ratios for the SNP using the AA genotype as the reference category for both control and case group. Adjustments were done towards controlling the potential confounding effect of age. Study population was also stratified according to ethnicity, controlling the variable as it could modify the outcome of analysis. $\mathrm{P}$ values are based on two sided probability test with a significance level of $P<.05$.

\section{Results}

The SNP present at Fas -670 for all controls and cases except one sample was successfully identified using the gel electrophoresis after treatment with $M v a \mathrm{I}$ restriction enzyme. Figure 1 shows the PCR fragmentation after restriction enzyme digestion. No deviation was found between the representative sequencing data chromatogram and the RFLP results. Figure 2 shows the sequencing chromatogram for each possible genotype after restriction enzyme digestion.

Next, Table 2 shows that no significant association was found in the general population between the Fas - 670 AG and GG genotype when compared to the AA genotype among females with cervical cancer. Even so, both AG and GG genotypes were non-significantly associated with lower odds ratio for cervical cancer when compared to the AA genotype. The dominant model analysis also shows a reduced association of AG and GG genotype compared to the referent wild type AA genotype $(\mathrm{OR}=0.57 ; 95 \% \mathrm{CI}=0.297-1.094)$. As for the stratified study population, no significant association was found in any of the stratified ethnic groups in the genotype analysis. Despite the lack of significant associations, the genotype GG reduces the odds of cervical cancer in the Malay and Indian ethnics but increases the cervical cancer odds in the Chinese ethnic. The AG genotype was also found to contribute to the non-significant reduction in odds of cer- 
vical cancer in all three ethnicities. However, no significant associations were found in the dominant model analysis and the allele frequency analysis in the general study population and in the ethnic-stratified study population. As with the genotype model analysis, the $\mathrm{G}$ allele is found to decrease cervical cancer odds in the Malay and Indian ethnic groups but increase the odds in the Chinese ethnic group. Further stratification according to cancer types, as shown in Table 3, did not show any significant association between the SNPs and cervical cancer.

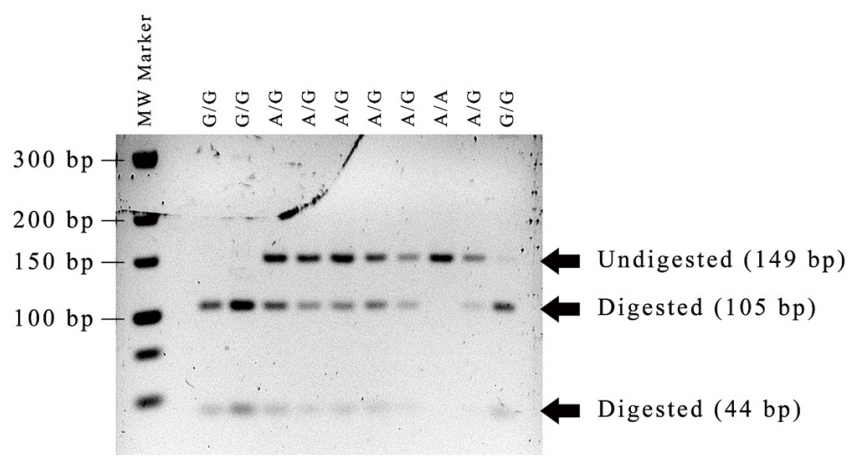

Figure 1. PCR bands after RFLP and gel electrophoresis. Fas -670 AA genotype is undigested by the MvaI enzyme and hence remains as a single 149 bp band. Homozygous GG genotypes are fully digested, forming two smaller bands, $105 \mathrm{bp}$ and $44 \mathrm{bp}$. Heterozygous AG genotype are partially digested resulting in 3 bands; 149 bp, 105 bp and 44 bp.

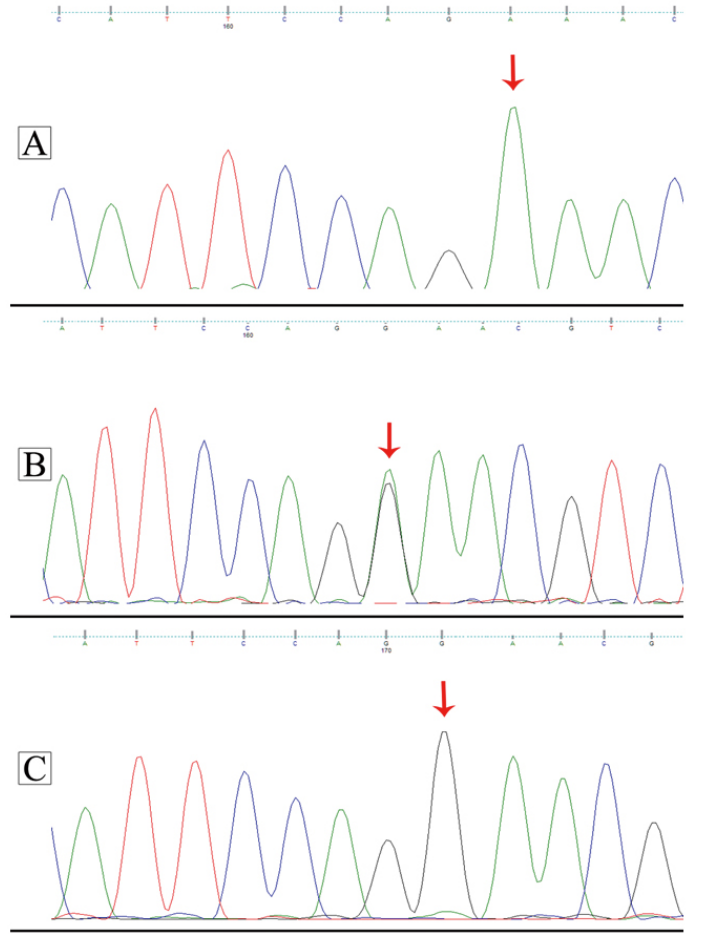

Figure 2. Sequencing chromatogram for the PCR amplicons. The arrow indicates the location of the Fas $-670 \mathrm{~A}>\mathrm{G}$ SNP. (A) shows the sequencing chromatogram obtained from a sample harbouring the homozygous A genotype. (B) shows a doublet peak of $\mathrm{A}$ and $\mathrm{G}$ nucleotides from a sample with heterozygous genotype. (C) shows a sample with homozygous $\mathrm{G}$ genotype.

Table 2. Fas -670 genotypes and alleles association with invasive cervical carcinoma

\begin{tabular}{|c|c|c|c|c|c|c|}
\hline Population (n) & Genotype (n; \%) & Controls (n; \%) & Cases (n; \%) & $\mathbf{O R}^{b}$ & $95 \%$ CI & $p$ value $^{d}$ \\
\hline \multirow[t]{5}{*}{ Total $(312)^{e}$} & A/A (73; 23.4\%) & $44(21.6 \%)$ & $29(26.9 \%)$ & $1^{a}$ & - & - \\
\hline & A/G (171; 54.8\%) & $116(56.9 \%)$ & 55 (50.9\%) & 0.556 & $0.282-1.096$ & .09 \\
\hline & G/G (68; 21.8\%) & $44(21.6 \%)$ & $24(22.2 \%)$ & 0.612 & $0.263-1.425$ & .255 \\
\hline & $\mathrm{G} / \mathrm{G}+\mathrm{A} / \mathrm{G}$ vs $\mathrm{A} / \mathrm{A}$ & - & - & 0.57 & $0.297-1.094$ & .091 \\
\hline & G allele (307; 49.2\%) & $204(50.0 \%)$ & $103(47.7 \%)$ & $0.912^{c}$ & $0.655-1.268$ & .641 \\
\hline \multirow[t]{5}{*}{ Malay (121) } & A/A $(21 ; 17.4 \%)$ & $8(12.1 \%)$ & $13(23.6 \%)$ & $1^{a}$ & - & - \\
\hline & A/G (65; 53.7\%) & 36 (54.5\%) & 29 (52.7\%) & 0.428 & 0.121-1.509 & .187 \\
\hline & G/G (35; 28.9\%) & 22 (33.3\%) & $13(23.6 \%)$ & 0.296 & $0.071-1.224$ & .093 \\
\hline & $\mathrm{G} / \mathrm{G}+\mathrm{A} / \mathrm{G}$ vs $\mathrm{A} / \mathrm{A}$ & - & - & 0.379 & $0.113-1.270$ & .116 \\
\hline & G allele (135; 55.8\%) & $80(60.6 \%)$ & 55 (50.0\%) & $0.650^{c}$ & $0.390-1.084$ & .127 \\
\hline \multirow[t]{5}{*}{ Chinese (132) } & A/A (36; 27.3\%) & $26(26.8 \%)$ & $10(28.6 \%)$ & $1^{a}$ & - & - \\
\hline & A/G (71; 53.8\%) & 54 (55.7\%) & 17 (48.6\%) & 0.701 & $0.250-1.965$ & .5 \\
\hline & G/G (25; 18.9\%) & 17 (17.5\%) & 8 (22.9\%) & 1.551 & $0.415-5.801$ & .515 \\
\hline & $\mathrm{G} / \mathrm{G}+\mathrm{A} / \mathrm{G}$ vs $\mathrm{A} / \mathrm{A}$ & - & - & 0.852 & $0.321-2.261$ & .748 \\
\hline & G allele (121; 45.8\%) & 88 (45.4\%) & $33(47.1 \%)$ & $1.074^{c}$ & $0.621-1.858$ & .907 \\
\hline \multirow[t]{5}{*}{ Indian (59) } & A/A (16; 27.1\%) & $10(24.4 \%)$ & $6(33.3 \%)$ & $1^{a}$ & - & - \\
\hline & A/G (35; 59.3\%) & $26(63.4 \%)$ & $9(50.0 \%)$ & 0.464 & $0.118-1.818$ & .27 \\
\hline & G/G (8; 13.6\%) & $5(12.2 \%)$ & $3(16.7 \%)$ & 0.522 & $0.068-4.032$ & .534 \\
\hline & $\mathrm{G} / \mathrm{G}+\mathrm{A} / \mathrm{G}$ vs $\mathrm{A} / \mathrm{A}$ & - & - & 0.473 & $0.126-1.783$ & .269 \\
\hline & G allele (51; 43.2\%) & 36 (43.9\%) & $15(41.7 \%)$ & $0.913^{c}$ & $0.413-2.018$ & .981 \\
\hline
\end{tabular}

Notes. ${ }^{a}$ Reference genotype. ${ }^{b}$ Unconditional logistic regression was used to obtain odds ratio: adjusted for age and ethnicity for overall study population; and age only for ethnic stratified population ${ }^{c}$ Crude odds ratio based on A allele as referent. ${ }^{d} p$ values are two tailed and $<.05$ is statistically significant. $P$ values for $\mathrm{G}$ allele are adjusted for Yates Correction for continuity. ${ }^{e}$ The SNP for one sample was non-identifiable and was excluded from the analysis. 
Table 3. Fas -670 genotypes and alleles association with invasive cervical carcinoma: by cancer type

\begin{tabular}{|c|c|c|c|c|c|c|c|}
\hline \multirow{2}{*}{ Genotype } & \multirow{2}{*}{$\begin{array}{l}\text { NILM } \\
\text { n (\%) }\end{array}$} & \multicolumn{3}{|c|}{ SCC } & \multicolumn{3}{|c|}{ ADC } \\
\hline & & n (\%) & OR (95\% CI) & $p^{d}$ & n (\%) & OR (95\% CI) & $p^{d}$ \\
\hline $\mathrm{A} / \mathrm{A}$ & $44(21.6 \%)$ & $11(30.6 \%)$ & $1^{a}$ & & $16(23.2 \%)$ & $1^{a}$ & - \\
\hline $\mathrm{A} / \mathrm{G}$ & 116 (56.9\%) & $18(50.0 \%)$ & $0.484(0.181-1.290)^{b}$ & .147 & $36(52.2 \%)$ & $0.720(0.321-1.614)^{b}$ & .425 \\
\hline G/G & 44 (21.6\%) & 7 (19.4\%) & $0.629(0.183-2.164)^{b}$ & .462 & $17(24.6 \%)$ & $0.772(0.288-2.069)^{b}$ & .607 \\
\hline $\begin{array}{l}\mathrm{G} / \mathrm{G}+\mathrm{A} / \mathrm{G} \\
\text { vs. A/A }\end{array}$ & - & - & $0.517(0.203-1.317)^{b}$ & .167 & - & $0.733(0.336-1.597)^{b}$ & .434 \\
\hline G allele & 204 (50.0\%) & $32(44.4 \%)$ & $0.800(0.483-1.324)^{c}$ & .458 & 70 (50.7\%) & $1.029(0.700-1.514)^{c}$ & .961 \\
\hline
\end{tabular}

Notes. ${ }^{a}$ Reference category. ${ }^{b}$ Unconditional logistic regression was used to obtain odds ratio: adjusted for age and ethnicity. ${ }^{c}$ Crude odds ratio based on A allele as referent. ${ }^{d}$ Statistical significant $P$ value is $<.05$. $P$ value is two tailed and adjusted for Yates Correction for continuity.

\section{Discussion}

The Fas gene is a critical gene in the regulation of apoptosis in cells. These cells may be afflicted by a multitude of conditions which result in cellular stress and DNA damage that requires the induction of cellular death to prevent widespread damage. Apoptosis may also be triggered in response to infection by HR-HPV, eliminating the infected cells prior to or during viral integration or even in response to cervical cancer. The Fas mediated apoptosis mechanism is triggered by interferon gamma from inflammatory cells. The interferon gamma proceeds to activate tyrosine kinase which phosphorylates STAT1 forming the tyrosine-STAT1 complex. The complex upon integrating with the nuclear transcription element of Fas promoter initiates gene transcription. ${ }^{[21]}$ After gene activation, Fas receptor proceeds to bind with its ligand, FasL, triggering the trimerization of the Fas receptor. An intracellular Fas-associated death domain (FADD) binds to the death effector domain (DED) on the Fas receptor. ${ }^{[22]}$ Pro-caspase- 8 and pro-caspase-10, the non-active initiator components of the caspase pathway then binds to FADD, resulting in the formation of the death-inducing signalling complex (DISC). ${ }^{[23]}$ The close proximity of these pro-caspases to the DISC allows them to be cleaved and become active caspase- 8 and caspase- 10 heterotetramers. ${ }^{[24,25]}$ Caspase- 8 and caspase-10 activates the subsequent caspase cascades, leading to the initiation of caspase- 3 and caspase- 7 which are able to release the caspase-activated deoxyribonuclease (CAD) from its inhibitor. The CAD enters the nucleus of the cell and proceeds to digest the DNA into small fragments ultimately causing apoptosis of the affected cell. ${ }^{[26]}$ This whole apoptosis triggering process can however be affected by the A to $\mathrm{G}$ base substitution in the STAT1 transcription factor binding site of Fas promoter where the A allele at the -670 SNP position was found to bind better to STAT1 than the $\mathrm{G}$ allele. ${ }^{[17,20]}$

In our present study on Malaysian females, there was no significant association between the Fas -670 polymorphism and the risk of cervical cancer using the genotype model, the dominant model and the allele frequency model analysis. There were no significant association even after the study population was stratified according to ethnic groups and cancer types. Despite the previously reported differences in the binding affinity between Fas and STAT1 due to the A>G SNP, our findings suggest that it does not predispose females with either SNP to cervical carcinoma in Malaysia. Similar observations had been previously made in the black and mixed ethnic females of South Africa, ${ }^{[27]}$ females of China ${ }^{[28,29]}$ and of South Korea. ${ }^{[30]}$ A study on Fas -670 and carcinoma in situ in Swedish females also found no significant association. ${ }^{[31]}$ More importantly, two recent meta-analysis studies compiling results of several different studies found no significant associations, even after stratification into Asian and Caucasian study groups. ${ }^{[32,33]}$ The lack of significant associations may be attributed to the absence of changes in the transcription activity of Fas. Despite the binding affinity of STAT1 to Fas -670 promoter region being affected by the variant allele, it was previously reported that the change in binding affinity might be insufficient towards statistically altering the expression of a reporter gene. ${ }^{[20]}$ Even so, there are a number of other studies which have reported otherwise. For example, the GG genotype and G allele has been noted to significantly increase risk of cervical carcinoma by 2.5 and 1.6 times respectively in Japanese females. ${ }^{[34]}$ There were also indications that synergistic effects of both A and $\mathrm{G}$ alleles contributed to cervical carcinogenesis as heterozygous $\mathrm{AG}$ genotype and the combined $\mathrm{AG}+\mathrm{GG}$ genotypes had significantly increased risk in North Indian females. ${ }^{[35]}$ Brazilian females under 48 years with the heterozygous AG genotype were also found to have 5-fold increase in risk compared to females with wild type AA genotype. ${ }^{[36]}$

Our findings do offer several interesting insights regarding the Fas SNP genotypes in the various ethnics in Malaysian females. Analysis of the allele frequencies in Malay and Indian females found that the $\mathrm{G}$ allele is less likely to cause 
cervical cancer compared to the referent A allele. The dominant model analysis in the Malay and Indian ethnicity also showed reduced risk for cervical cancer for the $A G+G G$ genotype when compared to the AA genotype. Given that the A allele was found to exhibit a higher binding affinity to STAT-1 than the G allele, one would have expected any variations from the $\mathrm{A}$ allele to result in the subpar function of the Fas gene. However, this was not unique to Malaysia as similar observations has been made in Taiwan where the A allele and AA genotype significantly increased the risk of high grade squamous intraepithelial lesions (HSIL) and SCC when compared to the $\mathrm{G}$ allele and GG genotype, by 1.26 and 1.83 times respectively. ${ }^{[37]}$ For the Malaysian Chinese females, the GG genotype and G allele increases risk of cervical carcinogenesis compared to their wild type counterpart. Interestingly, in contrast to the previously reported increase of cancer risk in both North Indian and Brazilian females by $\mathrm{AG},{ }^{[35,36]}$ the heterozygous genotype was associated with a reduction in cervical cancer risk in all the ethnicities in our study.

Cumulatively, our results suggest that despite the lack of significant associations, the $\mathrm{G}$ allele may exert protective effects towards cervical carcinogenesis in the Malay and Indian females but remains a potential risk factor in Chinese females. Our results also suggest that a cumulative presence of both $A$ and $G$ alleles may be critical in suppressing the development of cervical cancer.

Observations on the Fas -670 SNP genotype distributions in the different ethnics of Malaysia revealed further interesting results. The genotype distributions for $\mathrm{AA}, \mathrm{AG}$ and GG for Malay females $(17.4 \%, 53.7 \%$ and $28.9 \%$ respectively) were different from the genotypic distributions for Asian females, which tend to have AA genotype prevalence of $20 \%-40 \%{ }^{[29,30,34,37,38]}$ Interestingly, the genotype distribution for Malay females were more similar to those of mixed ancestry females in South Africa, albeit with lower GG prevalence. ${ }^{[27]}$ The genotypic distribution of AA genotype for Malaysian Chinese (27.3\%) was also less prevalent than in China $(\sim 44 \%),{ }^{[29]}$ showing evolutionary changes as a large majority of Chinese in Malaysia emigrated from China hundreds of years ago. Given that Malaysia is closer to the equator than China, the geographic location of a study population might exert more weight in determining SNP prevalence than the ethnic background. Even so, the ethnicity of a particular study population continues to be relevant since there are ethnic groups which are still confined to a single geographical location.

Furthermore, two other SNP risk factors have been recently suggested to work in tandem with Fas -670 in contributing towards deregulation of Fas expression and the carcinoma of the cervix. The Fas $-1377 \mathrm{G}>\mathrm{A}$ SNP is located in the silencer region in the 5' upstream region of the gene, though the site does not comply with any known silencer sequence. ${ }^{[39]}$ The SNP lies at the binding site of SP1 to the Fas gene, ${ }^{[17]}$ regulating the transcriptional activation of Fas. It has been suggested that binding of STAT1 alone was not sufficient for transcription activation and that synergistic SP1 binding was necessary. ${ }^{[40]} \mathrm{Li}$ and co-authors had recently reported that the variant forms of Fas -1337 and -670 SNPs were associated with a marked decrease in Fas gene expression and survivability in ovarian cancer in China. ${ }^{[41]}$ In cervical cancer, the -1377A/ -670A haplotype increased the odds for $-670 \mathrm{~A}$ alone from 1.26 to 3.05 in Taiwanese females. ${ }^{[37]}$ Therefore, variations of synergistic effects by both SNPs do exist, potentially resulting in variations of Fas expression level in different ethnicities. Alternatively, the FasL -844T $>C$ SNP is also a potential risk factor. The variant $C$ allele in the Fas ligand site $-844 \mathrm{~T}>\mathrm{C}$ is twice as active ${ }^{[42]}$ and are found to be more expressed in the $\mathrm{T}$ cells compared to the $\mathrm{T}$ allele, causing activation-induced cellular death (AICD) of the $\mathrm{T}$ cells and thereby increasing the risk in cervical cancer in females with the variant CC genotype by threefold. ${ }^{[29]}$ Additionally, Lai also reported that additive FasL $-844 \mathrm{CC}$ interaction increases the risk of HSIL/SCC to 2.13 times, higher than Fas -670AA alone in Taiwan implying that a synergistic effect was present. ${ }^{[37]}$ Fas -844 variant SNP has also been reported to help HPV infected cells escape lymphocytes mediated immune response by triggering the apoptosis of the Fas sensitive lymphocytes. ${ }^{[29,37,43]}$ This immune escape mechanism by FasL SNP therefore allows the HPV to persist in infected cervical cells, allowing for transformation of the cervical cells into more severe lesions. Furthermore, the type of HPV was not associated with the Fas -670 SNP, -1377 SNP or FasL -844 SNP, indicating that the down regulation of Fas expression was facilitated solely by the SNPs. ${ }^{[37]}$ Therefore, future studies incorporating both SNPs of Fas -1377 and FasL -844 into the studies of Fas -670 in Malaysian females could further identify the association of Fas and FasL SNP with cervical carcinogenesis.

Aside from that, future studies should also take into consideration several limitations present within the current study. Firstly, given that the SNP association analysis includes ethnic stratification, the sample size may have been too greatly diluted to produce significant association findings. Second, despite controlling for age and ethnicity, there are a number of other potential confounders and modifiers which may affect the outcome of the study. Factors which influence risk for cervical cancer such as infection with HPV, smoking, multi parity, oral contraceptives usage, early onset of sexual 
intercourse and multiple sexual partners may very well be confounders in the current study. ${ }^{[44-48]}$ Incorporating these socio-demographic factors will thereby also justify an increase in the sample size but overcoming these limitations in future studies may greatly improve the results, potentially providing more clarity in identifying SNP-malignancy associations.

\section{Conclusion}

This study observed no association between the Fas -670 SNP and cervical cancer in the female population of Malaysia, even after stratification according to ethnicity and cancer type. This indicates that the type of Fas -670 SNP does not predispose Malaysian females to, or protect them from cervical cancer. However, we suggest an increment in number of study subjects and better control of potential confounders to further improve future studies on the SNP. The incorporation of the additional risk factors Fas -1377 SNP and FasL -844 SNP in future studies involving Fas -670 SNP and cervical cancer may also be essential to identify the synergistic effects of these SNPs and cervical cancer risk in Malaysia.

\section{ACKNOWLEDGeMENTS}

The authors thank the participants of this study, the National Cancer Council Malaysia (MAKNA) for the funding of this study, Hospital Universiti Kebangsaan Malaysia for providing the samples in the study and Mr Sayyidi Hamzi for assisting with sample acquisitions.

\section{CONFLicts OF InTEREST Disclosure}

The authors declare that they have no competing interests.

\section{REFERENCES}

[1] Thompson CB. Apoptosis in the pathogenesis and treatment of disease. Science. 1995; 267(5203): 1456-62. PMid: 7878464. https : //doi.org/10.1126/science.7878464

[2] Budihardjo I, Oliver H, Lutter M, et al. Biochemical pathways of caspase activation during apoptosis. Annu Rev Cell Dev Biol. 1999; 15: 269-90. PMid: 10611963. https://doi.org/10.1146/annu rev.cellbio.15.1.269

[3] Mor G, Straszewski S, Kamsteeg M. Role of the Fas/Fas ligand system in female reproductive organs: survival and apoptosis. Biochem Pharmacol. 2002; 64(9): 1305-15. PMid: 12392813. https://doi.org/10.1016/S0006-2952(02)01267-4

[4] Hajra KM, Liu JR. Apoptosome dysfunction in human cancer. Apoptosis. 2004; 9(6): 691-704. PMid: 15505412. https://doi.org/ 10.1023/B: APPT.0000045786.98031.1d

[5] Ferlay J, Soerjomataram I, Dikshit R, et al. Cancer incidence and mortality worldwide: Sources, methods and major patterns in GLOBOCAN 2012. Int J Cancer. 2015; 136(5): E359-86. PMid: 25220842. https://doi.org/10.1002/ijc.29210

[6] Azizah AM, Nor Saleha IT, Noor Hashimah A, et al. Malaysian National Cancer Registry Report 2007-2011 [Internet]. 2016 [cited 2017 Aug 14]: 50-2. Available from: http://nci.moh.gov.my/index .php/ms/main-menu-2/laporan

[7] zur Hausen H, de Villiers EM. Human papillomaviruses. Annu Rev Microbiol. 1994; 48: 427-47. PMid: 7826013. https://doi.org/ 10.1146/annurev.mi.48.100194.002235

[8] Walboomers JM, Jacobs MV, Manos MM, et al. Human papillomavirus is a necessary cause of invasive cervical cancer worldwide. J Pathol. 1999; 189(1): 12-9. PMid: 10451482. https://doi.org/10.1002/(SICI) 1096-9896(19 9909) 189:1<12: :AID-PATH431>3.0.CO;2-F

[9] Barbisan G, Contreras A, Perez LO, et al. The effect of TP53 codon 72 and RNASEL codon 462 polymorphisms on the development of cervical cancer in Argentine women. Cancer Genetics. 2011; 204(5): 270-7. PMid: 21665181. https://doi.org/10.1016/j. cancer gen.2011.04.001

[10] Itoh N, Yonehara S, Ishii A, et al. The polypeptide encoded by the cDNA for human cell surface antigen Fas can mediate apoptosis. Cell. 1991; 66(2): 233-43. PMid: 1713127. https://doi.org/10.101 6/0092-8674(91) 90614-5

Published by Sciedu Press
[11] Nagata S, Golstein P. The Fas death factor. Science. 1995; 267(5203): 1449-56. PMid: 7533326. https://doi.org/10.1126/science. 7533326

[12] Suda T, Takahashi T, Golstein P, et al. Molecular cloning and expression of the Fas ligand, a novel member of the tumor necrosis factor family. Cell. 1993; 75(6): 1169-78. PMid: 7505205. https ://doi.org/10.1016/0092-8674(93)90326-L

[13] Ando K, Hiroishi K, Kaneko T, et al. Perforin, Fas/Fas ligand, and TNF-alpha pathways as specific and bystander killing mechanisms of hepatitis C virus-specific human CTL. J Immunol. 1997; 158(11): 5283-91. PMid: 9164947.

[14] Zamai L, Ahmad M, Bennett IM, et al. Natural killer (NK) cellmediated cytotoxicity: differential use of TRAIL and Fas ligand by immature and mature primary human NK cells. J Exp Med. 1998; 188(12): 2375-80. PMid: 9858524. https ://doi.org/10.1084/ jem.188.12.2375

[15] Leithauser F, Dhein J, Mechtersheimer G, et al. Constitutive and induced expression of APO-1, a new member of the nerve growth factor/tumor necrosis factor receptor superfamily, in normal and neoplastic cells. Lab Invest. 1993; 69(4): 415-29. PMid: 7693996.

[16] Hougardy BM, van der Zee AG, van den Heuvel FA, et al. Sensitivity to Fas-mediated apoptosis in high-risk HPV-positive human cervical cancer cells: relationship with Fas, caspase-8, and Bid. Gynecol Oncol. 2005; 97(2): 353-64. PMid: 15863130. https: //doi.org/10.1016/j.ygyno.2005.01.036

[17] Huang QR, Morris D, Manolios N. Identification and characterization of polymorphisms in the promoter region of the human Apo-1/Fas (CD95) gene. Mol Immunol. 1997; 34(8-9): 577-82. PMid: 9393960. https://doi.org/10.1016/S0161-5890(97)00081-3

[18] Sibley K, Rollinson S, Allan JM, et al. Functional FAS promoter polymorphisms are associated with increased risk of acute myeloid leukemia. Cancer Res. 2003; 63(15): 4327-30. PMid: 12907599.

[19] Schindler C, Darnell JE, Jr. Transcriptional responses to polypeptide ligands: the JAK-STAT pathway. Annu Rev Biochem. 1995; 64: 621-51. PMid: 7574495. https://doi.org/10.1146/annurev. bi.64.070195.003201

[20] Kanemitsu S, Ihara K, Saifddin A, et al. A functional polymorphism in fas (CD95/APO-1) gene promoter associated with systemic lupus erythematosus. J Rheumatol. 2002; 29(6): 1183-8. PMid: 12064832. 
[21] Xu X, Fu XY, Plate J, et al. IFN-gamma induces cell growth inhibition by Fas-mediated apoptosis: requirement of STAT1 protein for up-regulation of Fas and FasL expression. Cancer Res. 1998; 58(13): 2832-7. PMid: 9661898.

[22] Stegh AH, Schickling O, Ehret A, et al. DEDD, a novel death effector domain-containing protein, targeted to the nucleolus. EMBO J. 1998; 17(20): 5974-86. PMid: 9774341. https://doi.org/10.1093/ emboj/17.20.5974

[23] Kischkel FC, Hellbardt S, Behrmann I, et al. Cytotoxicity-dependent APO-1 (Fas/CD95)-associated proteins form a death-inducing signaling complex (DISC) with the receptor. EMBO J. 1995; 14(22): 5579-88. PMid: 8521815.

[24] Muzio M, Salvesen GS, Dixit VM. FLICE induced apoptosis in a cell-free system. Cleavage of caspase zymogens. J Biol Chem. 1997; 272(5): 2952-6. PMid: 9006941. https ://doi.org/10.1074/jb c. 272.5 .2952

[25] Scaffidi C, Kischkel FC, Krammer PH, et al. Analysis of the CD95 (APO-1/Fas) death-inducing signaling complex by high-resolution two-dimensional gel electrophoresis. Methods Enzymol. 2000; 322: 363-73. PMid: 10914030. https ://doi.org/10.1016/S0076-6 879 (00) 22033-8

[26] Scaffidi C, Kirchhoff S, Krammer PH, et al. Apoptosis signaling in lymphocytes. Curr Opin Immunol. 1999; 11(3): 277-85. PMid: 10375553. https ://doi.org/10.1016/S0952-7915(99 ) $80045-4$

[27] Chatterjee K, Engelmark M, Gyllensten U, et al. Fas and FasL gene polymorphisms are not associated with cervical cancer but differ among Black and Mixed-ancestry South Africans. BMC Res Notes. 2009; 2: 238. PMid: 19941645. https://doi.org/10.1186/17 56-0500-2-238

[28] Li H, Guo HY, Sun T, et al. [Association between Fas/Fas L genes promoter polymorphisms and pathogenic risk of cervical cancer]. Zhonghua Zhong Liu Za Zhi. 2009; 31(1): 38-41. PMid: 19538867.

[29] Sun T, Zhou Y, Li H, et al. FASL -844C polymorphism is associated with increased activation-induced $\mathrm{T}$ cell death and risk of cervical cancer. J Exp Med. 2005; 202(7): 967-74. PMid: 16186185 https://doi.org/10.1084/jem. 20050707

[30] Kang S, Dong SM, Seo SS, et al. FAS -1377 G/A polymorphism and the risk of lymph node metastasis in cervical cancer. Cancer Genet Cytogenet. 2008; 180(1): 1-5. PMid: 18068525. https: //doi.org/10.1016/j.cancergencyto.2007.09.002

[31] Engelmark MT, Renkema KY, Gyllensten UB. No evidence of the involvement of the Fas -670 promoter polymorphism in cervical cancer in situ. Int J Cancer. 2004; 112(6): 1084-5. PMid: 15316939. https://doi.org/10.1002/ijc. 20515

[32] Chen X, Mo W, Peng Q, et al. Lack of association between Fas rs 180082 polymorphism and risk of cervical cancer: an update by meta-analysis. BMC Med Genet. 2013; 14: 71. PMid: 23865866. https ://doi.org/10.1186/1471-2350-14-71

[33] Shen J, Sun NX. Association between FAS A670G polymorphism and susceptibility to cervical cancer: evidence from a meta-analysis. Tumour Biol. 2013; 34(6): 3443-8. PMid: 23900676. https: //doi.org/10.1007/s13277-013-0920-y

[34] Ueda M, Terai Y, Kanda K, et al. Fas gene promoter -670 polymorphism in gynecological cancer. Int J Gynecol Cancer. 2006; 16 Suppl 1: 179-82. PMid: 16515587. https://doi.org/10.1111/j.15 25-1438.2006.00505.x
[35] Kordi Tamandani DM, Sobti RC, Shekari M. Association of Fas670 gene polymorphism with risk of cervical cancer in North Indian population. Clin Exp Obstet Gynecol. 2008; 35(3): 183-6. PMid: 18754288.

[36] Zucchi F, da Silva ID, Ribalta JC, et al. Fas/CD95 promoter polymorphism gene and its relationship with cervical carcinoma. Eur J Gynaecol Oncol. 2009; 30(2): 142-4. PMid: 19480241.

[37] Lai HC, Lin WY, Lin YW, et al. Genetic polymorphisms of FAS and FASL (CD95/CD95L) genes in cervical carcinogenesis: An analysis of haplotype and gene-gene interaction. Gynecol Oncol. 2005; 99(1): 113-8. PMid: 15996722. https://doi .org/10.1016/j ·ygyno. 2005.05 .010

[38] Lai HC, Sytwu HK, Sun CA, et al. Single nucleotide polymorphism at Fas promoter is associated with cervical carcinogenesis. Int J Cancer. 2003; 103(2): 221-5. PMid: 12455036. https : //doi.org/10.1002/ijc. 10800

[39] Rudert F, Visser E, Forbes L, et al. Identification of a silencer, enhancer, and basal promoter region in the human CD95 (Fas/APO1) gene. DNA Cell Biol. 1995; 14(11): 931-7. PMid: 7576179. https://doi.org/10.1089/dna.1995.14.931

[40] Look DC, Pelletier MR, Tidwell RM, et al. Stat1 depends on transcriptional synergy with Sp1. J Biol Chem. 1995; 270(51): 30264-7. PMid: 8530443. https://doi.org/10.1074/jbc.270.51.30264

[41] Li Y, Hao YL, Kang S, et al. Genetic polymorphisms in the Fas and FasL genes are associated with epithelial ovarian cancer risk and clinical outcomes. Gynecol Oncol. 2013; 128(3): 584-9. PMid: 23234803. https://doi.org/10.1016/j.ygyno.2012.12.002

[42] Wu J, Metz C, Xu X, et al. A novel polymorphic CAAT/enhancerbinding protein beta element in the FasL gene promoter alters Fas ligand expression: a candidate background gene in African American systemic lupus erythematosus patients. J Immunol. 2003; 170(1): 132-8. PMid: 12496392. https://doi.org/10.4049/jimmunol .170 .1 .132

[43] Strand S, Hofmann WJ, Hug H, et al. Lymphocyte apoptosis induced by CD95 (APO-1/Fas) ligand-expressing tumor cells-a mechanism of immune evasion? Nat Med. 1996; 2(12): 1361-6. PMid: 8946836. https : //doi .org/10.1038/nm1296-1361

[44] Louie KS, de Sanjose S, Diaz M, et al. Early age at first sexual intercourse and early pregnancy are risk factors for cervical cancer in developing countries. Br J Cancer. 2009; 100(7): 1191-7. PMid: 19277042. https://doi.org/10.1038/sj.bjc. 6604974

[45] Munoz N, Franceschi S, Bosetti C, et al. Role of parity and human papillomavirus in cervical cancer: the IARC multicentric casecontrol study. Lancet. 2002; 359(9312): 1093-101. PMid: 11943256. https://doi .org/10.1016/S0140-6736(02)08151-5

[46] Sikstrom B, Hellberg D, Nilsson S, et al. Smoking, alcohol, sexual behaviour and drug use in women with cervical human papillomavirus infection. Arch Gynecol Obstet. 1995; 256(3): 131-7. PMid: 7574905. https://doi .org/10.1007/BF01314641

[47] Smith JS, Green J, Berrington de Gonzalez A, et al. Cervical cancer and use of hormonal contraceptives: a systematic review. Lancet. 2003; 361(9364): 1159-67. PMid: 12686037. https://doi.org/ 10.1016/S0140-6736(03) 12949-2

[48] Wang LE, Cheng L, Spitz MR, et al. Fas A670G polymorphism, apoptotic capacity in lymphocyte cultures, and risk of lung cancer. Lung Cancer. 2003; 42(1): 1-8. PMid: 14512182. https: //doi.org/10.1016/S0169-5002(03)00276-9 